\title{
PENERAPAN TEKNOLOGI PENGIDERAAN JAUH DI BIDANG PESISIR DAN LAUTAN
}

\author{
Oleh \\ Muhammad Zainuddin Lubis ${ }^{1)}$, Oktavianto Gustin ${ }^{1)}$, Wenang Anurogo', \\ Husnul Kausarian², Kasih Anggraini ${ }^{3)}$, Aditya Hanafi'
}

\begin{abstract}
APPLICATIONS OF REMOTE SENSING TECHNOLOGY IN COASTAL AND OCEAN Many remote sensing applications are devoted to the coastal and ocean sector. Representative case studies are presented in the special issue "Advances in Remote Sensing of coastal and ocean". Remote sensing techniques represent a powerful tool for landslide investigation: applications are traditionally sea surface temperature, marine habitat into three main classes, although this subdivision has some limitations and borders are sometimes fuzzy in coastal and ocean. Remote sensing combined with geographic information system (GIS) can be used as a technology tool to obtain information about the object quickly and accurately, including objects in coastal and ocean areas. Remote sensing data on coastal and marine areas specifically for the region in Indonesia have been widely practiced. The use of remote sensing data and GIS in coastal and marine areas can be used to determine sea surface temperature, determination of fish catchment area, and coastline morphological changes by adding other influential parameters. It can also be used to monitor a regional change by using multi-temporal recording data such as disaster monitoring, monitoring of land cover changes in coastal areas etc. Remote sensing data essentially can be used as an alternative technology in obtaining information at a cheaper cost when compared with the conventional way.
\end{abstract}

\section{PENDAHULUAN}

Penginderaan jauh menjadi salah satu alternatifmemperoleh informasi yang cepat, tepat dan murah. Penginderaan jauh adalah ilmu untuk memperoleh informasi fenomena alam pada objek (permukaan bumi) yang diperoleh tanpa kontak langsung dengan objek permukaan bumi, tetapi melalui pengukuran pantulan (reflection) ataupun pancaran (emission) oleh media gelombang elektromagnetik (Suwargana, 2013). Menurut Jaya (2010), penginderaan jarak jauh khususnya satellite remote sensing dengan citra landsat merupakan sarana yang banyak digunakan untuk kegiatan pemetaan di bidang kelautan dan pesisir di Indonesia.

Aplikasi penginderaan jauh

\footnotetext{
1) Dosen Teknik Geomatika, Politeknik Negeri Batam (zainuddinlubis@polibatam.ac.id)

2) Dosen Teknik Geologi, Fakultas Tenik, Universitas Islam Riau (UIR)

3) Staf Pusat Penelitian Oseanografi LIPI

4) Mahasiswa Program Studi Teknik Geomatika
} 
merupakan salah satu aplikasi yang dapat dimanfaatkan untuk analisis tingkat kenyamanan permukiman di daerah kota. Aplikasi penginderaan jauh mampu dalam menyadap informasi secara detil, karena memberikan resolusi spasial yang cukup tinggi. Informasi tersebut dapat berupa liputan vegetasi, kepadatan bangunan, jarak permukiman terhadap jalan utama dan industri yang merupakan beberapa parameter penentu tingkat kenyamanan permukiman. Pemanfaatan SIG digunakan untuk menganalisis parameter yang berpengaruh dalam tingkat kenyamanan permukiman dan membantu dalam memvisualisasikan dalam bentuk peta (Maru, 2016).

Karakter utama citra (image) dalam penginderaan jauh adalah adanya rentang kanal (band) panjang gelombang elektromagnetik (electromagnet wavelength) yang dimilikinya. Beberapa radiasi yang dapat dideteksi dengan sistem penginderaan jauh, seperti radiasi cahaya matahari yang dapat terdeteksi melaui medium gelombang elektromagnetik. Daerah panjang gelombang elektromagnetik dari daerah visible dan near sampai middle infrared, atau dari distribusi spasial energi panas (thermal) yang dipantulkan dari permukaan bumi. Setiap material pada permukaan bumi mempunyai reflektansi yang berbeda terhadap cahaya matahari, sehingga material-material tersebut akan mempunyai resolusi yang berbeda pada setiap band panjang gelombang. Obyek di permukaan bumi berdasarkan pada nilai pantulan energi gelombang elektromagnetik yang dipancarkan oleh obyek permukaan bumi kemudian energi tersebut direkam oleh sensor. Ada tiga kelompok utama obyek permukaan bumi yang dapat dideteksi oleh sensor yaitu: air, tanah, dan vegetasi yang masing-masing memancarkan energi elektromagnetik dengan kemampuan pemetaan citranya tergantung pada karakteristik masing-masing citra satelit. Kanal dan karakteristik inilah yang digunakan oleh penginderaan jauh untuk mengenali obyek-obyek atau tipe-tipe liputan lahan yang ada di permukaan bumi (Suwargana, 2013)

Saat ini penelitian tentang terumbu karang mengenai distribusi, kondisi (tingkat kerusakan) dan luasannya masih dilakukan dengan cara konvensional yang masih mempunyai banyak kelemahan, selain membutuhkan biaya yang cukup besar juga sulit mendapatkan data yang secara sinoptik dan bersifat spasial dalam areal yang luas. Sebagai solusi dari masalah ini, sekarang sudah tersedia sarana satelit (Citra Landsat_TM) yang dapat digunakan untuk mendapatkan data secara sinoptik dan bersifat spasial dalam areal yang luas tersebut. Contohnya adalah penelitian untuk mengetahui distribusi dan tingkat kerusakan terumbu karang yang terjadi dalam kurun waktu 5 tahun terakhir, serta luasannya (terbatas pada kedalaman 0-10 meter) dengan menggunakan citra satelit Landsat_TM Aquisisi Tahun 1997 dan 2002 (Rauf, 2004).

Koreksi citra satelit yang digunakan pada penelitian ini adalah citra satelit Landsat 8 tahun 2005 hasil perekaman 12 Januari 2005 yang digunakan sebagai garis pantai awal (baseline), dan hasil perekaman 12 September 2014 sebagai 
garis pantai pembanding. Pengolahan citra satelit dilakukan untuk mengoreksi hasil perekaman citra satelit dengan kondisi sebenarnya di lapangan. Pengolahan citra satelit terdiri dari koreksi atmosferik dan koreksi geometrik (Anggoro et al., 2015).

\section{Koreksi Atmosferik}

Proses koreksi atmosferik yang dilakukan menggunakan modul FLAASH pada perangkat lunak Envi. Koreksi atmosferik bertujuan untuk menghilangkan pengaruh atmosfer, seperti partikel debu dan uap air (Manson et al., 2003). Tahap koreksi atmosferik menggunakan FLASSH adalah yang berfungsi sebagai berikut: 1) Kalibrasi nilai digital citra menjadi nilai radian dalam format band interleaved by line (BIL); 2) Menentukan titik tengah scene citra, tipe sensor, ketinggian sensor, ukuran piksel dan akuisisi yang terdapat pada metadata citra; 3) Menentukan ketinggian rata-rata lokasi penelitian dan menentukan model atmosferik yaitu tropikal dan model aerosol maritim; dan 4) Memasukan nilai kecerahan udara.

\section{Koreksi Geometrik}

Koreksi geometrik yang dilakukan dalam metode penginderaan jauh, dengan menggunakan data GCP (Ground Control Point) hasil pengukuran lapangan berdasarkan persamaan polinomial (Mishra et al., 2006; Wenang et al., 2015). Penentuan posisi GCP dilakukan pada lokasi yang dianggap tidak berubah atau berpindah selama tahun 2005-2014 seperti dermaga, persimpangan jalan dan menara. Posisi lokasi GCP pada penelitian ini disajikan pada Lampiran 1. Koreksi geometrik dilakukan dengan cara nilai koordinat baris dan kolom ditransformasi secara matematis menjadi koordinat dengan sistem proyeksi yang telah ditentukan. Persamaan polinomial dipilih untuk mengurangi kesalahan koordinat. Akurasi dari transformasi polinomial dihitung dengan menggunakan RMSE (Root Mean Square Error) untuk setiap GCP.

\section{PERANAN PENGINDERAAN JAUH DAN SIG}

Adapun upaya untuk memperoleh informasi tentang potensi sumberdaya wilayah pesisir dan lautan dalam rangka untuk mengoptimalkan pengelolaan wilayah pesisir dan lautan adalah penggunaan teknologi penginderaan jauh dan sistem informasi geografis (SIG). Informasi mengenai obyek yang terdapat pada suatu lokasi di permukaan bumi diambil dengan menggunakan sensor satelit, kemudian sesuai dengan tujuan kegiatan yang akan dilakukan, informasi mengenai obyek tersebut diolah, dianalisa, diinterpretasikan dan disajikan dalam bentuk informasi spasial dan peta tematik tata ruang dengan menggunakan SIG. Pemanfaatan data penginderaan jauh dan SIG telah banyak dilakukan dalam kaitannya dengan wilayah pesisir dan lautan khususnya sektor perikanan dan pengelolaan wilayah pesisir dan lautan, seperti aplikasi penginderaan jauh untuk memberikan informasi Zona Potensi Penangkapan Ikan (ZPPI), kesesuaian lahan perairan untuk usaha budidaya laut dan pariwisata bahari, identifikasi potensi wilayah pesisir (seperti hutan mangrove, terumbu karang, padang lamun dan pasir), 
zonasi kawasan konservasi laut, analisa potensi ekonomi wilayah pesisir pulaupulau kecil, pengamatan perubahan garis pantai, analisa pencemaran lingkungan perairan dan lain sebagainya. (Syah, 2010).

Pemetaan dibidang perairan dan lautan pernah dilakukan yaitu tentang Pemetaan Sumber Daya Laut Pulau Nias dengan Teknologi Penginderaan Jauh Satelit Pasca-Tsunami 2004 (Gaol et al., 2007). Pemanfaatan data penginderaan jauh di antaranya untuk penelitian tentang model pengembangan wilayah pesisir dan lautan. Penelitian dimulai dari pengembangan model parameter fisik perairan (suhu permukaan laut, klorofil, muatan padat tersuspensi, kecerahan perairan) wilayah pesisir (Gaol et al., 2014)

Penelitian yang dilakukan dengan kegiatan suhu permukaan laut dan klorofil ini di antaranya adalah Yuan et al (2004), dengan cara menurunkan algoritma kecerahan perairan dengan model Seichi Disk Transparency (DSP) menggunakan data satelit Landsat multi temporal (Oktaviani \& Johan, 2016).

Absorbsi gelombang infra merah oleh air dan reflektansi beberapa jenis panjang gelombang yang kuat terhadap jenis obyek vegetasi dan tanah menjadikan teknik kombinasi ini ideal dalam memetakan distribusi perubahan darat dan air yang diperlukan dalam pengekstraksian perubahan garis pantai. Teknik ini dilakukan dengan on screen digitizing yang terlebih dahulu dibuat kontras, deteksi sisi dengan cara filtering, atau segmentasi histogram (Suhana et al., 2017). Dalam tulisan ini diuraikan beberapa pendekatan teknik gabungan dalam kegiatan penginterprestasian garis pantai menggunakan dataset citra Landsat, dan deskripsi untuk teknik analisis perubahannya di lingkungan SIG (Kasim, 2012).

\section{TEKNOLOGI MODERN PENGINDERAAN JAUH}

Teknologi modern Sistem Informasi Geografi dan penginderaan jauh dapat digunakan untuk mendapatkan data spasial digital dengan cepat dan akurat, sehingga mampu menjawab masalah kebutuhan informasi para pemangku kebijakan. Multi konsep dalam inderaja mampu memberikan berbagai informasi spasial dan multi informasi yang lain (seperti multi spektral, multi sensor, multi spasial, multi waktu, multi polarisasi dan multi tahap). Aplikasi teknologi inderaja yang multi konsep tersebut dapat dimanfaatkan untuk memprediksi luas area panen dan produktivitasnya, sehingga tingkat ketersediaan beras nasional dapat diprediksi tiap musim panen. Metodologi inderaja yang banyak menggunakan citra satelit optik, yang digunakan saat ini, seringkali terkendala oleh tutupan awan, terutama pada saat musim hujan (Shofiyati, 2011). Disamping itu ketergantungan pada data satelit memerlukan biaya yang besar serta lambatnya pengadaan data sehingga menyebabkan informasi Teknologi Pesawat Tanpa Awak untuk Pemetaan dan Pemantauan Tanaman dan Lahan Pertanian perlu diterapkan (Riadi \& Makmuriyanto, 2014). Pemotretan udara dengan menggunakan pesawat tanpa 
awak merupakan salah satu teknologi alternatif untuk mendapatkan data lebih detil, real time, cepat dan lebih murah. (Putranto et al., 2016).

Terkait dengan bertambah baiknya resolusi spasial data pengindaran jauh, maka dimungkinkan untuk mengekstrasi objek-objek yang relatif lebih rinci dalam ukurannya. Begitu pula dengan bertambah baiknya resolusi spektral dari data pengindaraan jauh, maka memungkinkan data satelit dapat digunakan untuk mengekstrasi informasi atau objek didasarkan pada nilai spektral dari objek tertentu. Nilai spektral dari setiap objek yang di observasi biasanya berbeda. Khusus untuk objek yang berbeda di bawah permukaan laut (seperti terumbu karang, padang lamun, dan sebagainya) (Sari \& Lubis, 2017), dan nilai spektral dipengaruhi oleh beberapa faktor antara lain: sifat fisik objek, dimensi objek, kejernihan atau kekeruhan air, kedalaman air dan sebagainya (Arya et al., 2017).

Mengacu pada kegiatan MREP (Marine Resources And Evaluation Planning) yang dilakukan olehpemerintah pada tahun 1999 - 2002, maka perlu adanya kegiatan survei dan penelitian tentang sumber daya kelautan di daerah. Hasil yang diperoleh dapat menjadi dasar pengembangan dan pengelolaan sumber daya kelautan dan perikanan secara terpadu. Salah satu teknologi yang dapat digunakan dalam kegiatan survey dan penelitian potensi sumber daya kelautan dan perikanan adalah teknologi SIG.

\section{PENERAPAN TEKNOLOGI PENGIDERAAN JAUH DI BIDANG KELAUTAN INDONESIA}

Penerapan teknologi penginderaan jauh di bidang kelautan Indonesia saat ini sangat banyak dilakukan, salah satunya adalah metode pendeteksian karakteristik atau habitat dasar perairan dangkal. Penggunaan dengan metode konvensional menyebabkan pemetaan dasar perairan dangkal memerlukan waktu yang lama, dan biaya yang relatif mahal. Contoh penelitian yang dilakukan oleh peneliti yang pernah menggunakan penginderaan jauh dalam pemetaannya adalah Siregar (2010) menggunakan citra QuickBird adalah untuk memetakan dasar perairan dangkal di Kepulauan Seribu; Restuning \& Handayani (2007) dengan menggunakan data citra dari USGS tahun 1973-2006 dalam hasil pemetaan pola gempa bumi di Indonesia; Usman et al., (2005) dengan menggunakan citra Lansat TM dalam penelitian sedimentasi perairan lagoon Segara Anakan; dan Simbolon (2010) menggunakan data citra modis dalam menentukan daerah penangkapan ikan cakalang melalui analisis Suhu Permukaan Laut (SPL) di Teluk Pelabuhan Ratu. Penelitian tentang Pemanfaatan Citra Landsat 8 pernah dilakukan untuk memetakan persebaran lamun di wilayah pesisir Pulau Batam oleh Sari \& Lubis (2017). Pemetaan parameter oseanografi fisik menggunakan citra landsat 8 di wilayah perairan Nongsa Pulau Batam oleh Lubis \& Daya (2017), dan Pemetaan potensi kekeringan lahan seluruh Pulau Batam, dengan menggunakan teknik Sistem Informasi Geografis dan penginderaan jauh oleh Aprilliyanti \& Zainuddin (2017). 
Pendekatan penginderaan jauh kelautan dengan parameter oseanografi sangat sering dilakukan di Indonesia, yakni dengan melihat pengaruh gelombang laut. Pengembangan kawasan pantai yang tidak dilandasi oleh prinsip perlindungan dan pelestarian lingkungan, dapat menyebabkan terjadinya kerusakan pada fungsi ekologis yang berakibat terjadinya kerusakan kawasan pantai (Angkotasan, 2012).

Salah satu hal yang dapat dilakukan dalam mengkaji kondisi suatu kawasan pantai adalah melalui studi mengenai perubahan garis pantai (Sakka et al., 2011). Sebagai contoh adalah untuk menganalisis perubahan garis pantai, melalui tumpang susun (overlay) citra satelit. Beberapa penelitian sebelumnya yang mengkaji tentang perubahan garis pantai di berbagai kawasan pantai menggunakan citra satelit dilakukan oleh Yulius \& Ramdhan (2013). Kemudian Purba \& Jaya (2004) melakukan penelitian mengenai perubahan garis pantai yang dilakukan di lokasi pesisir Kabupaten Lampung Timur, dengan menggunakan citra satelit Landsat, dengan menyebutkan faktor morfologi pantai, variasi arah angin dan karakteristik gelombang laut, yang ditelaah sebagai faktor yang berperan terhadap perubahan garis pantai di pesisir Kabupaten Lampung Timur.

Kemajuan teknologi di bidang penginderaan jauh kelautan juga dirasakan dalam bidang pemetaan di Indonesia. Teknologi pemetaan saat ini sudah menggunakan jasa satelit, sehingga sangat memudahkan masyarakat untuk untuk mendapatkan data Citra Modis, dengan mengunduh langsung melalui situs http://oceancolor.gsfc.nasa. gov (Simbolon, 2010). Restuning \& Handayani (2007) mendapatkan data citra gempa bumi yang dapat diambil dari katalog gempa bumi milik United States Geological Survey (USGS).

\section{PENUTUP}

Tulisan ini memberikan informasi tentang bagaimana pentingnya teknik penginderaan jauh di bidang pesisir dan lautan, Pengetahuan tentang perkembangan dan metode dengan penggunaan citra satelit untuk pemetaan dan eksplorasi di bidang pesisir dan lautan akan sangat membantu. Penggunaan metode konvensional, menyebabkan pemetaan dasar perairan dangkal memiliki banyak keterbatasan seperti memerlukan waktu yang lama dan biaya yang relatif mahal. Oleh karena itu, pemanfaatan citra satelit penginderaan jauh sebagai salah satu solusi alternatifnya.

\section{DAFTAR PUSTAKA}

Anggoro, A. V.P. Siregar dan S.B. Agus. 2015. Pemetaan zona geomorfologi ekosistem terumbu karang menggunakan metode OBIA, studi kasus Pulau Pari. Penginderaan Jauh. 12 (1): 1-12.

Angkotasan, A.M., I.W. Nurjaya dan N.M.N. Natih. 2012. Analisis perubahan garis pantai di pantai barat daya Pulau Ternate, Provinsi Maluku Utara. Jurnal Ilmu dan Teknologi Kelautan Tropis. 3 (1): 11-22. 
Anurogo, W., S.H Murti, dan N. Khakhim. 2015. Analisis Perubahan Hutan Mangrove Dalam Penentuan Kawasan Rehabilitasi Dan Perubahan Stok Karbon Menggunakan Data Penginderaan Jauh (Di Teluk Banten, Serang Provinsi Banten). [Thesis]. UGM (ID): Universitas Gadjah Mada, Yogyakarta, pp. 1-99.

Aprilliyanti, T. dan M. Zainuddin . 2017. Pemetaan Potensi Kekeringan Lahan se-pulau Batam menggunakan Teknik Sistem Informasi Geografis (SIG) dan Penginderaan Jauh. Majalah Geografi Indonesia, 31(1), 91-94.

Arief, M. 2010. Inventarisasi Sumber Daya Alam Pesisir dan Laut dengan Menggunakan Data Satelit Landsat Studi Kasus: Kabupaten Maluku Tenggara. Majalah Sains dan Teknologi Dirgantara, 1(2), 114-128.

Arya, A., G. Winarso dan I. Santoso. 2017. Ekstraksi Kedalaman Laut Menggunakan Data Spot-7 di Teluk Belangbelang Mamuju (The Bathymetry Extraction Using Spot-7 Data At The Belangbelang Bay Waters Mamuju). Jurnal Ilmiah Geomatika, 22(1), 09-19.

Felde G.W., G.P. Anderson, T.W. Cooley, M.W. Matthew, S.M. AdlerGolden, A. Berkand and J. Lee. 2003. Analysis of Hyperion Data with the FLAASH Atmospheric Correction Algorithm. 2003.
IEEE IGARSS: Learning from Earth's Shapes and Colors: Toulouse: $\mathrm{p}$ 90-92.

Gaol, J.L., R.E. Arhatin, D. Manurung dan M Kawaru. 2007. Pemetaan Sumber Daya Laut Pulau Nias dengan Teknologi Penginderaan Jauh Satelit Pasca-Tsunami 2004. Jurnal Ilmu Pertanian Indonesia, 12(3), 131-140.

Gaol, J.L., R.E. Arhatin dan M.M. Ling. 2014. Pemetaan Suhu Permukaan Laut Dari Satelit di Perairan Indonesia Untuk Mendukung "One Map Policy". In Seminar Nasional Penginderaan Jauh (pp. 433442).

Jaya I. 2011. Penginderaan jauh sumberdaya dan dinamika laut dengan teknologi akustik untuk pembangunan benua maritim Indonesia. Orasi Ilmiah Guru Besar FPIK-IPB. IPB-Press. Bogor.

Kasim, F. 2012. Pendekatan beberapa metode dalam monitoring perubahan garis pantai menggunakan dataset penginderaan jauh Landsat dan SIG. Jurnal Ilmiah Agropolitan, 5, 620-635.

Lubis, M.Z.Z. dan A.P. Daya. 2017. Pemetaan Parameter Oseanografi Fisik Menggunakan Citra Landsat 8 di Wilayah Perairan Nongsa Pulau Batam. Jurnal Integrasi, 9(1), 9-15. 
Manson, F. J., N.R. Loneragan, G.A. Skilleterand and S.R. Phinn. 2005. An evaluation of the evidence for linkages between mangroves and fisheries: a synthesis of the literature and identification of research directions. Oceanography and marine biology, 43, 483.

Maru, A.C.H. dan I.N. Hidayati. 2016. Pemanfaatan Citra Quickbird dan Sig Untuk Pemetaan Tingkat Kenyamanan Permukiman Di Kecamatan Semarang Barat Dan Kecamatan Semarang Utara. Jurnal Bumi Indonesia, 5(1). 10-20.

Mishra, D., S. Narumalani, D. Rundquistand and M. Lawson. 2006. Benthic habitat mapping in tropical marine environments using QuickBird multispectral data. Photogrammetric Engineering \& Remote Sensing, 72(9), 1037-1048.

Oktaviani, A. dan Y. Johan. 2016. Perbandingan Resolusi Spasial, Temporal dan Radiometrik Serta Kendalanya. Jurnal Enggano, 1(2), 74-79.

Purba M dan I. Jaya. 2004. Analisis perubahan garis pantai dan penutupan lahan antara Way Penet dan Way Sekampung, Kabupaten Lampung Timur. Jurnal Ilmu-ilmu Perairan dan Perikanan Indonesia. 11 (2): 109-121.
Putranto, A., S. Sutikno dan S. Suharyadi. 2016. Integrasi Foto Udara dan Sistem Informasi Geografis Untuk Evaluasi Penentuan Letak Bangunan Candi Di Wilayah Prambanan, Klaten, Jawa Tengah dan Daerah Istimewa Yogyakarta. Majalah Geografi Indonesia, 29(1), 1-6.

Rauf, A. dan M. Yusuf. 2004. Studi Distribusi dan Kondisi Terumbu Karang dengan Menggunakan Teknologi Penginderaan Jauh di Kepulauan Spermonde, Sulawesi Selatan. Ilmu Kelautan. Indonesian Journal of Marine Sciences, 9(2), 7481.

Restuning, D.G dan L. Handayani. 2007. Pemetaan Pola Terjadinya Gempa Bumi di Indonesia Dengan Metode Fraktual. Jurnal Riset Geologi Dan Pertambangan. 17(2): 51-56.

Riadi, B. dan A. Makmuriyanto. 2014. Kajian Percepatan Penetapan dan Penegasan Batas Kecamatan/Distrik, Desa/ Kelurahan Secara Kartometris. Majalah Ilmiah Globe, 16(2), 109-116.

Sakka, M. Purba, I.W. Nurjaya, H. Pawitan dan V.P. Siregar. 2011. Studi perubahan garis pantai di Delta Sungai Jeneberang, Makassar. Jurnal Ilmu dan Teknologi Kelautan Tropis. 3 (2): 112-126. 
Sari, D.P. dan M.Z. Lubis. 2017. Pemanfaatan Citra Landsat 8 Untuk Memetakan Persebaran Lamun di Wilayah Pesisir Pulau Batam. Jurnal Enggano, 2(1), 39-45.

Shofiyati, R. 2011. Teknologi pesawat tanpa awak untuk pemetaan dan pemantauan tanaman dan lahan pertanian. Informatika Pertanian, 20(2), 58-64.

Simbolon, D. 2010. Eksplorasi Daerah Penangkapan Ikan Cakalang Melalui Analisis Suhu Permukaan Laut dan Hasil Tangkapan Di Perairan Pelabuhan Ratu. Jurnal Mangrove Dan Pesisir. 10(1): 42-49.

Suhana, M.P., I.W. Nurjaya dan N.M. Natih. 2017. Analisis Kerentanan Pantai Timur Pulau Bintan, Provinsi Kepulauan Riau Menggunakan Digital Shoreline Analysis System dan Metode Coastal Vulnerability Index. Jurnal Teknologi Perikanan Dan Kelautan, 7(1), 21-38.

Suwargana, N. 2013. Resolusi Spasial, Temporal dan Spektral pada Citra Satelit Landsat, Spot dan Ikonos. Jurnal Ilmiah Widya, 1(1), 167-174.
Syah, A. F. 2010. Penginderaan Jauh dan Aplikasinya di Wilayah Pesisir dan Lautan. Jurnal Kelautan. Indonesian Journal of Marine Science and Technology, 3(1), 18-28.

Usman. E. dan L. Sarmili. 2005. Rekontruksi Proses Sedimentasi Perairan Lagoon Segara Anakan. Jurnal Geologi Kelautan. 3(3):15-25.

Yuan, F., K.E. Sawaya, B.C. Loeffelholz and M.E. Bauer. 2005. Land cover classification and change analysis of the Twin Cities (Minnesota) Metropolitan Area by multitemporal Landsat remote sensing. Remote sensing of Environment, 98(2), 317328.

Yulius dan M. Ramdhan. 2013. Perubahan garis pantai di Teluk Bungus Kota Padang, Provinsi Sumatera Barat berdasarkan analisis citra satelit. Jurnal Ilmu dan Teknologi Kelautan Tropis. 5 (2): 41-72. 